\title{
THE RESULTS OF THE EMBRYO TRANSFER TO HEIFERS FROM THE AYRSHIRE BREED
}

\author{
Constantin Nimbona ${ }^{1}$, Nadezhda I. Kulikova ${ }^{1}$, \\ Joseph Butore ${ }^{2}$, Melance Ntunzwenimana ${ }^{2}$ \\ ${ }^{1}$ Kuban State Agrarian University \\ Krasnodar, 350044, Russian Federation \\ ${ }^{2}$ University of Burundi \\ Bujumbura, 1233, Burundi \\ cosnim120@yahoo.fr
}

\begin{abstract}
Dairy cattle's breeding is an important industry, since it is providing milk and meat to population. Modern cows are significantly different from their ancestors in biology, behavior and in productivity. The scientific approach to feeding, condition of content and formation of focused heredity contributed to increasing the cows' productivity. During the mammary gland formation and sexual cycles manifestation, puberty occurs, which makes it possible to obtain offspring and secretion of milk for feeding calves. The modern cows are capable of producing milk for their calves and for feeding people. The appearance of record cows, giving about $100 \mathrm{~kg}$ per day, and during lactation more than 32 tons of milk serves as an example for achieving such indicators of production. There are negative effects in reproduction biology, which takes place in modern cattle breeding. In order to breed highly productive cows, it is important to increase their livestock by intensive selection. Modernity is such that fertility is reduced due to cows' reproductive functions inhibition. Modern practice shows that it is possible to introduce methods of obtaining several calves from one cow. It is generally accepted for this purpose use new reproduction methods, for example transplantation of embryos with high genetic potential. This technique is widely used in biotechnology of cows breeding. We have tested the method of preparing and conducting embryo transfer to heifers from 13 to 16 months old in the Kuban Agro-Association.

The article presents indicators of heifer. It was revealed that not all animals reacted positively to superstimulation. Embryo transplantation showed that $35.1 \%$ of embryos survived after embryo transfer. Economic calculations have shown that for the rapid formation of a highly productive herd on the farm, it is advisable to use Ayrshire breed heifers capable of raising embryos and giving birth to healthy calves as recipients.
\end{abstract}

Key words: heifer, recipient, hormones, stimulation, embryo, transplantation, embryo survival, calf

\section{INTRODUCTION}

A significant increase in milk production of cows affects the formation of lactation dominant, which suppresses the intensity of the manifestation of the reproductive functions and fertility of animals [1]. The inverse relationship between the physiology of cows and heifers between the production of calves and the increase in milk productivity is caused by the development of biotechnology, which allows for the rapid reproduction of highly productive herds of cows [2]. The beginning of the biotechnology was developed in the UK, methods for obtaining and freezing mouse embryos, and then from 
40 species of mammals [3, 4]. The cattle embryo transplantation technique developed in the past is now widely used in many countries. This allowed us to quickly create whole herds of highly productive cows.

Currently, in some farms of the Krasnodar region, for reproduction of highly productive cows, they have mastered and are implementing methods for embryo transplantation, the highest Holstein cattle breed in the world, and heifers were used as recipients $[4,5]$.

The purpose of our research was to study and master the method of embryo transfer and analyze the results of their survival rate in Ayrshire heifers.

\section{MATERIAL AND METHODS}

We have carried out studies on dairy farms 'AgroAssociation'. For our research, Ayrshire heifer breeds selected on farms were used for farming, taking into account their breed, origin and level of productivity of the cows, as well as health and reproductive functions.

The general purpose of research is studying and mastering the methods of selection, preparation of recipients and transplantation of embryos to Ayrshire calves. To carry out the scientific experience, 2 groups of Ayrshire breed were formed: $1^{\text {st }}$ control group that includes animals without hormonal stimulation and $2^{\text {nd }}$ experimental group of heifers, which have been stimulated for superovulation (Table 1).

Table 1

Scheme of experiment

\begin{tabular}{|l|l|c|l|}
\hline \multicolumn{1}{|c|}{$\begin{array}{c}\text { №№ experimental } \\
\text { groups }\end{array}$} & \multicolumn{1}{|c|}{$\begin{array}{c}\text { Experimental animals } \\
\text { Ayrshire breed }\end{array}$} & $\begin{array}{c}\text { The number } \\
\text { of animals, heads }\end{array}$ & \multicolumn{1}{c|}{ Hormonal stimulation } \\
\hline I control & heifers & 20 & without stimulation \\
\hline II experimental & heifers & 17 & hormone stimulation \\
\hline
\end{tabular}

Recipients were selected in 2 stages. At the first stage, Ayrshire breed heifers were selected according to age from $14^{\text {th }}$ to $16^{\text {th }}$ months, at the second stage by external exterior features, level of health, physiological condition of the animal.

The criterion for the selection of recipients heifers were taken into account the requirements for mothers' milk production less than $6,000 \mathrm{~kg}$ for 305 days of lactation; with strong constitution, an exterior of the milk-like animal, a live weight around $400 \mathrm{~kg}$ or more, the metabolic activity of potential recipients, a positive reaction to hormonal scheme, maternal insemination index 1.5 and at his $3^{\text {rd }}$ sexual cycles or more. The recipient must be a physiologically healthy animal: the uterus is located in the pelvic cavity, the cervix is clearly expressed, the length of the horns of the uterus is $20-35 \mathrm{~cm}$, without adhesions and tumors, an active corpus luteum of the ovary, measuring $1-1.5 \mathrm{~cm}$. We did not use heifers as recipients when there were both a corpus luteum and a follicle. Clinically healthy animals: score body $-2.75-3.50$ points, without lameness and gastrointestinal tract, and the respiratory and digestive organs lesions. The first group of the control group did not perform hormonal stimulation until embryo transfer at the $16^{\text {th }}$ day. Animals of the experimental group from the first to $16^{\text {th }}$ days were carried out according to the superovulation program, and $1 \mathrm{ml}$ of Fertagyl was administered to the animals of the control group before embryos transplantation (Table 2). 
Scheme of stimulation of Ayrshire breed recipients for embryo grafting

\begin{tabular}{|l|l|l|}
\hline \multirow{2}{*}{$\begin{array}{c}\text { Drug administration } \\
\text { time }\end{array}$} & \multicolumn{2}{|c|}{ Groups of recipients who received drugs } \\
\cline { 2 - 3 } & \multicolumn{1}{|c|}{ 1 control group (heifers) } & \multicolumn{1}{c|}{2 experimental (heifers) } \\
\hline $1^{\text {st }}$ day $7^{00}$ & not stimulated & Fertagyl + CIDR \\
\hline $7^{\text {th }}$ day $7^{00}$ & not stimulated & remove CIDR + Dinolytic $-5 \mathrm{ml}$ \\
\hline $9^{\text {th }}$ day $7^{00}$ & not stimulated & Fertagyl $-1 \mathrm{ml}$ \\
\hline $16^{\text {th }}$ day $7^{00}$ & Fertagyl $1 \mathrm{ml}+$ embryo transplantation & Fertagyl $1 \mathrm{ml}+$ embryo transplantation \\
\hline
\end{tabular}

Embryo transfer to recipients was performed only to animals that responded positively to the introduction of hormones. The process of embryo transplantation was performed together with inseminator specialists and fresh embryos were used.

\section{RESULTS OF RESEARCH}

\section{Characteristics of Ayrshire calves (recipients)}

For embryo transplantation, 37 animals of the Ayrshire breed were selected. The selected heifers - recipients were 12.9-15.6 months old. The heifers of both experimental groups had well-defined status characteristic of highly dairy animals: the head and neck were light, the neck had of medium length, gradually turning into shoulders, deep, but moderately wide chest, flat, straight back, well developed body muscles, strong legs and straight limbs.

We studied the survival rate of embryos in recipient heifers of $1^{\text {st }}$ and $2^{\text {nd }}$ groups. An important step in the transplantation process is the selection, assessment of the state of health and timely introduction of embryos to recipients. In order to determine the optimization of the transplantation technique, we first carried out the embryo transfer of the heifers that have not received the hormonal stimulation ( $1^{\text {st }}$ control group), and then we transferred the embryos using the same technique to the recipients, who had hormonal treatment in order to prepare them for the embryo transplantation $\left(2^{\text {nd }}\right.$ experimental group). After embryo transfer, recipients of both groups were constantly monitored to evaluate embryonic survival and development stage of embryos. Pregnancy status was determined for the first time by ultrasound, 31 days after embryo transplantation, and by transrectal palpation of the uterus 60 days after embryo transplantation.

A trans-rectal examination of the uterus for pregnancy diagnosis allowed confirming or not the status and stage of pregnancy, check the viability of the fetus, and confirm the normal topography of the uterus to diagnose various pathologies of pregnancy. Rectal examination distinguished the characteristic features of the uterus: fluctuation of pregnancy, palpation of embryonic membranes, palpation of the embryo and fetus, palpation of the cotyledon and uterine artery. Ultrasound diagnosis of pregnancy allowed us to visualize the front and back of the embryo on the $31^{\text {st }}$ day of pregnancy. After 60 days of pregnancy, we considered the development of the spinal column of the orbital cavity of the fetus, the formation of the bones of the head, mouth and skull. According to statistics, the early definition of pregnancy in heifers - recipients was evaluated at $46.1 \%$ of animals. 
As a result of research, the survival rates of embryos in recipients were determined. A total of 37 embryos were transplanted to 37 heifers - recipients of Ayrshire breed. Survival rate of embryos in females that have not undergone superovulation ( $1^{\text {st }}$ group) was $20.0 \%$. In heifers that exposed to hormonal stimulation before embryo transfer, the survival rate was higher by $32.9 \%$ (Table 3 ).

The results allow us to conclude that it is not advisable to use heifers as recipients without hormonal stimulation, as proved that only 4 heifers $(20.0 \%)$ were pregnant in the control group, between 14 and 15.8 months old (the average was 14.95 months). In the heifers of the experimental group - from 13.3 - 16.5 months old (on average 15.53 months $)-9$ embryos survived (52.9\% of pregnancy).

Table 3

Results of embryonic survival in heifers Ayrshire breed

\begin{tabular}{|l|c|c|c|}
\hline \multirow{2}{*}{ Animal groups } & \multicolumn{2}{|c|}{ Indicators } \\
\cline { 2 - 4 } & $\begin{array}{c}\text { transferred } \\
\text { embryos, nbr. }\end{array}$ & $\begin{array}{c}\text { pregnant recipients, } \\
\text { heads }\end{array}$ & $\begin{array}{c}\text { embryomic survival rate, } \\
\%\end{array}$ \\
\hline $\begin{array}{l}1 \\
\text { control, heifer recipients } \\
\text { without stimulation }\end{array}$ & 20 & 4 & 20.0 \\
\hline $\begin{array}{l}2 \\
\text { experimental, heifers - } \\
\text { recipients, with hormon } \\
\text { stimulation }\end{array}$ & 17 & 9 & 52.9 \\
\hline Total & 37 & 13 & \\
\hline
\end{tabular}

It is important to note that recipient heifers must be physically developed. Analysis showed that animal body weight of group control ranged from 416 to $469 \mathrm{~kg}$, with an average of $448.5 \mathrm{~kg}$, while the recipient heifers from experimental group varied from 437 to $470 \mathrm{~kg}$ (average - $452.3 \mathrm{~kg}$ ).

\section{Cost-effectiveness of embryo transfer to heifers - Ayrshire breed recipients}

The use of embryo transfer techniques in dairy cattle breeding allowed to increase significantly and quickly the milk yield of cows on all continents. In terms of the number of transplanted embryos in dairy cattle breeding, the countries of Europe and North America are leaders (151,257 collected and 111,575 embryos transplanted). The cost of selling semen bioproducts and embryos from outstanding animals in genetics is very high. In Russia, embryo transfer in cattle breeding is being introduced in farms with high production efficiency, as this is an economically costly technique.

We have evaluated the economic efficiency of embryo transplantation in the Kuban Agricultural Association. The costs of the embryo transplantation process consist of the costs of a hormonal scheme - stimulation of ovulation in recipients and processing of embryos transfer. The cost of the calf embryo will depend on the reproductive functions of the recipients, their preparation, as well as on the professionalism of embryo transplantation specialists. Total costs for embryo transfer are higher in the experimental group due to the high cost (3600 rub/head) of hormonal stimulation. The total costs per recipient of the control group amounted to $-8,000$ rubles (without stimulation), 
in the experimental group - 11,600 rubles. Evaluation of embryo survival in recipients showed that in the control group (without hormonal stimulation) $20.0 \%$ of the recipients were pregnant, and in the experimental group (hormonally stimulated) $-52.9 \%$. The difference in survival rate of embryos was 2.6 times higher in hormone-stimulated heifers, compared with non-stimulated ones.

Calves from heifers that did not receive stimulation are more expensive in comparison with heifers stimulated by hormones due to high rate of pregnancy and calving from them. However, an economic assessment show that for larger quantities of embryos obtained from animals have more highly advisable to use hormonal stimulation of the heifers - recipients before embryo transfer by the proposed method.

\section{CONCLUSIONS}

Based on the data obtained as a result of research, the following conclusions can be made:

The farm breeds cattle of Holstein and Ayrshire. Prolonged use of Holstein bulls with high genetic potential of milk production: milk yield from 13,692 to $14,925 \mathrm{~kg}$ of milk, fat content from 3.73 to $4.55 \%$, protein from $3.10-3.23 \%$ in milk made it possible to achieve milk production in cows Holstein breed more than $10,000 \mathrm{~kg}$ of milk, $3.79 \%$ fat and $3.57 \%$ protein;

It is known that the increase in milk productivity of cows reduces the ability of animals to reproduce, and also reduces productive longevity in the current technological conditions. For the purpose of rapid reproduction of the livestock of highly productive livestock in the farm, a decision was made to introduce the method of embryo transplantation from highly productive animals. In 2014, a laboratory was set up and equipped to prepare donors and recipients, and a method was tested for obtaining embryos from donors and transfer them to recipients. With it, the solutions are: to use Holstein heifers as donors, and Ayrshire heifers as recipients.

C) Nimbona C, Kulikova NI, Butore J, Ntunzwenimana M., 2019.

\section{REFERENCES}

[1] Nimbona K, Kulikova NI, Mehonoshin MV. Selection and superovulation of cows of donors and recipients during embryo transplantation. In: Innovation in increasing the productivity of farm animals. Collection of articles on the materials of the international scientific-practical conference. Krasnodar, 19 October 2017. Krasnodar: KubGau Publ.; 2017. p. 129—135. (In Russ).

[2] Nimbona K, Kulikova NI. Planning the study of the formation of a selection group of cows in breeding farms using embryo transplantation. In: Collection of articles on the materials of the X All-Russian Conference of Young Scientists dedicated to the 120th anniversary of I.S. Kosenko 24-30 November 2016. Scientific support of the agro-industrial complex. Krasnodar: KubGau Publ.; 2017. p. 252-253. (In Russ).

[3] Roper DA, Schrick FN, Edwards JL, Hopkins FM, Prado TM, Wilkerson JB, Saxton AM, Young CD, Smith WB. Factors in cattle affecting embryo transfer pregnancies in recipient animals. Animal Reproduction Science. 2018; 199:79—83.Available from: doi: 10.1016/ j.anireprosci.2018.11.001. 
[4] Shcherbak OV, Zyuzyun AB, Kovtun SI. Cryopreservation of embryos as a method of preserving the gene pool of white-headed Ukrainian cattle breed. Dairy and Beef Cattle. 2017; (2):21-23. (In Russ).

[5] Lim HJ, Yoon HB, Im SK. Relationship between growth pattern, age at first calving and next reproduction in Holstein heifers. J. Emb. Trans. 2015; 30(4):265-270. Available from: http://db.koreascholar.com/article.aspx? code $=311768$.

[6] Bó GA, Baruselli PS, Moreno D, Cutaia L, Caccia M, Tríbulo R, Tríbulo H, Mapletoft RJ. The control of follicular wave development for self-appointed embryo transfer programs in cattle. Theriogenology. 2002; 57(1):53 - 72. Available from: doi: 10.1016/S0093-691X(01)00657-4.

[7] Colazo MG, Gordon MB, Rajamahendran R, Mapletoft RJ, Ambrose DJ. Pregnancy rates to timed artificial insemination in dairy cows treated with gonadotropin-releasing hormone or porcine luteinizing hormone. Theriogenology. 2009; 72(2):262-270. Available from: doi: 10.1016/j.theriogenology.2009.02.017.

[8] Nabenishi H, Sugino F, Konaka R, Yamazaki A. Conception rate of Holstein and Japanese Black cattle following embryo transfer in southwestern Japan. Animal science Journal. 2018; 89(8):1073-1078. Available from: doi: 10.1111/asj.13042.

\title{
Information about authors
}

Nimbona Constantin - DVM, M.Sc., PhD student, Department of Private Zootechnics and Pig farming, Faculty of Zootechny, Kuban State Agrarian University, Krasnodar, Russian Federation; e-mail: conim120@yahoo.fr

Kulikova Nadezhda Ivanovna - Dr. of Agr. Sc., Professor, Department of Private Zootechny and pig farming, Kuban State Agrarian University, Krasnodar, Russian Federation; e-mail: kulikova_ni@bk.ru

Butore Joseph - DVM, PhD, Department of Agronomy and Bio-engineering, University of Burundi, Bujumbura, Burundi; e-mail: butojo07@yahoo.fr

Ntunzwenimana Melance - DVM, PhD, Department of Agronomy and Bio-engineering, University of Burundi, Bujumbura, Burundi; e-mail: ntunzwe@yahoo.fr

\section{For citation:}

Nimbona C, Kulikova NI, Butore J, Ntunzwenimana M. The results of the embryo transfer to heifers from the Ayrshire breed. RUDN Journal of Agronomy and Animal Industries, 2019, 14 (1), 66-72. doi: 10.22363/2312-797X-2019-14-1-66-72.

\section{РЕЗУЛЬТАТЫ ТРАНСПЛАНТАЦИИ ТЕЛКАМ ЭМБРИОНОВ, ПОЛУЧЕННЫХ ОТ АЙРШИРСКОЙ ПОРОДЫ}

\author{
К. Нимбона ${ }^{1}$, Н.И. Куликова ${ }^{1}$, \\ Ж. Буторе ${ }^{2}$, М. Нтунвенимана ${ }^{2}$ \\ ${ }^{1}$ Кубанский государственный аграрный университет \\ Краснодар, Российская Федеращия, 350044 \\ ${ }^{2}$ Университет Бурунди \\ Бужумбура, Бурунди, 1233
}

\begin{abstract}
Аннотация. Молочное скотоводство - важная отрасль, так как ее основная задача - обеспечить молоком и мясом население. Методически в процессе длительного использования коров человек научился ухаживать, кормить и получать потомство от них. Современные коровы сущест-
\end{abstract}


венно отличаются от своих предков, не только по биологии, поведением, но и продуктивностью. Научный подход к кормлению, условиям содержания и целенаправленному формированию наследственности способствовали повышению продуктивности коров. При формировании молочной железы у молодых телок и проявлении половых циклов наступает половое созревание, которое дает возможность получения потомства и секрецию молока для выкармливания телят. Коровы современной генетики способны давать молоко не только для своих телят, но и для питания людей. Появление коров-рекордисток, дающих в сутки около 100 кг, а за лактацию более 32 т молока, служит примером для достижения таких показателей в условиях производства. Достичь рекордных удоев сложно, не возможно. При этом проявляются негатив в биологии размножения, что имеет место в современном скотоводстве. С целью разведения высокопродуктивных коров важно увеличить их поголовье, для интенсивного отбора и подбора животных. Современность такова, что снижается плодовитость за счет угнетения воспроизводительных функций коров при высокой лактации. Современные походы науки и практики свидетельствуют о том, что возможен для внедрения в производство способ получения нескольких телят от одной коровы. Общепринято для этого применять новые биотехнологии методы воспроизводства, например трансплантацию эмбрионов с высокой генетикой.

Такая методика достаточно широко используется в биотехнологии размножения коров путем трансплантации эмбрионов. Нами апробирована методика подготовки и проведения трансплантации эмбрионов телкам-реципиентам в возрасте от 13 до 16 месяцев в предприятии «Агрообъединение Кубань». В статье представлены показатели генотипа телок-реципиентов. Выявлено, что в процессе подготовки реципиентов не все животные положительно отреагировали на гормональную стимуляцию овуляции. Трансплантация эмбрионов показала, что прижились эмбрионы у 35,1\% телокреципиентов. Экономические расчеты показали, что для быстрого формирования высокопродуктивного стада в хозяйстве целесообразно использовать в качестве реципиентов телок айрширской породы, способных вырастить эмбрионы и родить здоровых телят.

Ключевые слова: телка, реципиент, гормоны, стимуляция, эмбрион, трансплантация, приживаемость, теленок

\section{БИБЛИОГРАФИЧЕСКИЙ СПИСОК}

[1] Нимбона К., Куликова Н.И., Мехоношин М.В. Отбор и суперовуляция коров доноров и реципиентов при трансплантации эмбрионов // Инновации в повышении продуктивности сельскохозяйственных животных. 2017. С. 129-135.

[2] Нимбона К., Куликова Н.И. Планирование изучения формирования селекционной группы коров в племенном хозяйстве при использовании трансплантации эмбрионов // Научное обеспечение агропромышленного комплекса. 2017. С. 252-253.

[3] Roper D.A., Schrick F.N., Edwards J.L., Hopkins F.M., Prado T.M., Wilkerson J.B., Saxton A.M., Young C.D., Smith W.B. Factors in cattle affecting embryo transfer pregnancies in recipient animals // Animal reproduction science. 2018. T. 199. C. 79-83.

[4] Щербак О.В., Зюзюн А.Б., Ковтун С.И. Криоконсервация эмбрионов как метод сохранения генофонда белоголовой украинской породы крупного рогатого скота // Молочное и мясное скотоводство. 2017. № 2. С. 21-23.

[5] Lim H.J., Yoon H.B., Im S.K. Relationship between growth pattern, age at first calving and next reproduction in Holstein heifers // Journal of Embryo Transfer. 2015. T. 30. № 4. C. 265-270.

[6] Bó G.A., Baruselli P.S., Moreno D., Cutaia L., Caccia M., Tríbulo R., Tríbulo H., Mapletoft R.J. The control of follicular wave development for self-appointed embryo transfer programs in cattle // Theriogenology. 2002. T. 57. № 1. C. 53-72.

[7] Colazo M.G., Gordon M.B., Rajamahendran R., Mapletoft R.J., Ambrose D.J. Pregnancy rates to timed artificial insemination in dairy cows treated with gonadotropin-releasing hormone or porcine luteinizing hormone // Theriogenology. 2009. T. 72. № 2. C. 262-270.

[8] Nabenishi H., Sugino F., Konaka R., Yamazaki A. Conception rate of Holstein and Japanese Black cattle following embryo transfer in southwestern Japan // Animal Science Journal. 2018. T. 89. №. 8. C. $1073-1078$. 